\title{
ST-Depression as a Risk Indicator for the Occurrence of Postoperative Cardiovascular Complications in Emergency Abdominal Surgery
}

\author{
M Matveev \\ Centre of Biomedical Engineering - Bulgarian Academy of Sciences, Sofia, Bulgaria
}

\begin{abstract}
Data on 466 patients subjected to emergency abdominal surgery were used to synthesise indices for prediction of cardiovascular complications during the postoperative period on the basis of ST-depression as a manifestation of real or relative myocardial ischaemia. The indices are presented as intervals of values for individual groups of surgical diseases and various age intervals. The total index is related to the determination of the risk of occurrence of cardiovascular complications of all levels of severity, and the lethal index - to determination of the risk of lethal (severe) cardiovascularincidents.
\end{abstract}

\section{Introduction}

Cardiovascular complications in the perioperative period are a serious problem in modern noncardiac surgery [1,2].

Emergency major surgery is characterised by the short time for making therapeutic decisions, the considerable severity of the basic surgical pathology and the critical general condition of the patients. Under these conditions, the evaluation of cardiac risk becomes particularly important $[1,2,3]$.

In most studiesreal or relative myocardial ischaemia is cited as the cause for perioperative cardiovascular complications (CVC) [3, 4]. Consequently, it is justifiable to link the assessment of the cardiac risk in emergency noncardiac surgery with the electrocardiographically determined ST-depression (STd).

\section{Material and methods}

The synthesis of cardiac risk assessment indices (CRI) was made on the basis of data from the treatment of 466 patients (average age 57.0, SD \pm 19.4 ) who have undergone emergency abdominal surgery in connection with the five most frequent groups of surgical diseases - Table 1.

CRI reflect the incidence of CVC in patients with and without STd - Table 2 and Fig. 1-5. For the surgical diseases groups (SDG), on the basis of the ratios between: (1) the frequencies of all $\mathrm{CVC}$ in the patients

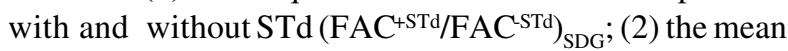
ages of the patients with and without STd $\left(\mathrm{MA}^{+\mathrm{STd}} / \mathrm{MA}^{-\mathrm{STd}}\right)_{\mathrm{SDG}}$, while the total CRI (TCRI) was identifie d as the ratio of the frequencies of all CVC in the patients with and without STd, corrected with respect to the following average ages:

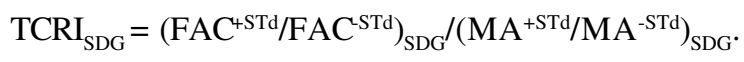

TCRI $_{\text {SDG }}$ assesses the "net" contribution of STd for raising the risk of occurrence of CVC for each SDG. The index is related to a conditional patient whose age is equal to the mean age for the population studied. For a concrete patient with STd the risk assessment is corrected with the ratio between his age (PA) and the mean age of the population studied with STd in the respective SDG:

$$
\mathrm{PCRI}_{\mathrm{SDG}}=\mathrm{TCRI}_{\mathrm{SDG}} \mathrm{x}\left(\mathrm{PA} / \mathrm{MA}^{+\mathrm{STd}}\right) \text {. }
$$

The lethal CRI (LCRI) for assessing the risk of occurrence of lethal (severe) CVC was similarly determined:

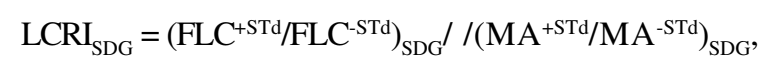

and its age-personalised value

$$
\mathrm{PLCRI}_{\mathrm{SDG}}=\mathrm{LCRI}_{\mathrm{SD}} \times\left(\mathrm{PA} / \mathrm{MA}^{+\mathrm{STd}}\right) \text {. }
$$

FLC $^{+ \text {STd }}$ and FLC -STd $^{-1}$ are accordingly the frequencies of the lethal CVC in patients with and without STd.

Student's frequent $t$-test was used for verification of the hypothesis about the significance of the difference in the incidences of CVC according to SDG [5]. 
Table 1. Distributions of patients with and without STd according to CVC types and SDG.

\begin{tabular}{|c|c|c|c|c|c|c|c|c|c|c|c|}
\hline \multirow[b]{2}{*}{$\begin{array}{l}\text { Group of } \\
\text { surgical } \\
\text { diseases }\end{array}$} & \multicolumn{3}{|c|}{ Number } & \multicolumn{2}{|c|}{ Total number CVC } & \multicolumn{3}{|c|}{ Lethal CVC } & \multicolumn{3}{|c|}{ Non-lethal CVC } \\
\hline & $\begin{array}{c}\text { patients } \\
\text { without } \\
\text { STd }\end{array}$ & $\begin{array}{l}\text { patients } \\
\text { with STd }\end{array}$ & $\begin{array}{c}\text { Total } \\
\text { patients }\end{array}$ & $\begin{array}{l}\text { in } \\
\text { patients } \\
\text { without } \\
\text { STd }\end{array}$ & $\begin{array}{c}\text { in } \\
\text { patients } \\
\text { with STd }\end{array}$ & $\begin{array}{l}\text { number } \\
\text { in } \\
\text { patients } \\
\text { without } \\
\text { STd }\end{array}$ & $\begin{array}{l}\text { number } \\
\text { in } \\
\text { patients } \\
\text { with STd }\end{array}$ & $\begin{array}{c}\text { total } \\
\text { number }\end{array}$ & $\begin{array}{l}\text { number } \\
\text { in } \\
\text { patients } \\
\text { without } \\
\text { STd }\end{array}$ & $\begin{array}{l}\text { number } \\
\text { in } \\
\text { patients } \\
\text { with STd }\end{array}$ & $\begin{array}{c}\text { total } \\
\text { number }\end{array}$ \\
\hline A & 92 & 10 & 102 & 5 & 4 & 0 & 0 & 0 & 5 & 4 & 9 \\
\hline B & 79 & 13 & 92 & 26 & 10 & 1 & 1 & 2 & 25 & 9 & 34 \\
\hline $\mathrm{C}$ & 71 & 13 & 84 & 24 & 8 & 2 & 2 & 4 & 22 & 6 & 28 \\
\hline $\mathrm{D}$ & 82 & 26 & 108 & 29 & 17 & 6 & 4 & 10 & 23 & 13 & 36 \\
\hline $\mathrm{E}$ & 63 & 17 & 80 & 34 & 12 & 11 & 6 & 17 & 23 & 6 & 29 \\
\hline Total & 387 & 79 & 466 & 118 & 51 & 20 & 13 & 33 & 98 & 38 & 136 \\
\hline
\end{tabular}

A - acute appendicitis, B - complicated abdominal hernia, C - complicated ulcers and neoplasms of the upper gastrointestinal tract, D - hepatic-pancreatic-biliary diseases, E - acute states in pathology of the lower gastrointestinal tract

Table 2. CVC and age profiles in surgical diseases groups

\begin{tabular}{|c|c|c|c|c|c|c|c|c|c|c|c|c|}
\hline \multirow[t]{2}{*}{$\begin{array}{l}\text { Group } \\
\text { of } \\
\text { surgical } \\
\text { diseases }\end{array}$} & \multicolumn{2}{|c|}{$\begin{array}{l}\text { Total number of } \\
\text { CVC to the } \\
\text { number of patients } \\
\text { (in \%) in the group } \\
\text { accordingly }\end{array}$} & \multicolumn{2}{|c|}{$\begin{array}{l}\text { Number of lethal } \\
\text { CVC to the total } \\
\text { number of CVC (in } \\
\% \text { ) in patients }\end{array}$} & \multicolumn{2}{|c|}{$\begin{array}{l}\text { Number of non- } \\
\text { lethal CVC to the } \\
\text { total number of } \\
\text { CVC (in \%) in } \\
\text { patients }\end{array}$} & \multicolumn{2}{|c|}{$\begin{array}{l}\text { Number of lethal } \\
\text { CVC to the } \\
\text { number of patients } \\
\text { (in \%) in the group } \\
\text { accordingly }\end{array}$} & \multicolumn{2}{|c|}{$\begin{array}{l}\text { Number of lethal } \\
\text { to the number of } \\
\text { non-lethal CVC (in } \\
\% \text { ) in patients }\end{array}$} & \multicolumn{2}{|c|}{$\begin{array}{l}\text { Mean age of the } \\
\text { patients in the } \\
\text { SDG accordingly }\end{array}$} \\
\hline & $\begin{array}{c}\text { without } \\
\text { STd }\end{array}$ & $\begin{array}{l}\text { with } \\
\text { STd }\end{array}$ & $\begin{array}{c}\text { without } \\
\text { STd }\end{array}$ & $\begin{array}{l}\text { with } \\
\text { STd }\end{array}$ & $\begin{array}{c}\text { without } \\
\text { STd }\end{array}$ & $\begin{array}{l}\text { with } \\
\text { STd }\end{array}$ & $\begin{array}{c}\text { without } \\
\text { STd }\end{array}$ & $\begin{array}{l}\text { with } \\
\text { STd }\end{array}$ & $\begin{array}{c}\text { without } \\
\text { STd }\end{array}$ & $\begin{array}{l}\text { with } \\
\text { STd }\end{array}$ & $\begin{array}{c}\text { without } \\
\text { STd }\end{array}$ & $\begin{array}{l}\text { with } \\
\text { STd }\end{array}$ \\
\hline A & 5.5 & 40 & 0 & 0 & 5.5 & 40 & 0 & 0 & 0 & 0 & 37 & 58 \\
\hline B & 33 & 77 & 4 & 10 & 32 & 69 & 1 & 8 & 3 & 12 & 69 & 75 \\
\hline $\mathrm{C}$ & 34 & 62 & 8 & 25 & 31 & 46 & 3 & 15 & 10 & 33 & 61 & 68 \\
\hline $\mathrm{D}$ & 35 & 73 & 21 & 24 & 28 & 50 & 7 & 23 & 25 & 46 & 55 & 63 \\
\hline $\mathrm{E}$ & 54 & 71 & 32 & 50 & 37 & 35 & 17 & 35 & 50 & 100 & 62 & 72 \\
\hline
\end{tabular}

A - acute appendicitis, B - complicated abdominal hernia, C - complicated ulcers and neoplasms of the upper gastrointestinal tract, D - hepatic-pancreatic-biliary diseases, E - acute states in pathology of the lower gastrointestinal tract

\section{Results}

STd was registered preoperatively in $79(17 \%)$ of the patients. The mean age ( 66.8 years, $\mathrm{SD} \pm 12.9$ years $)$ of the patients with STd is significantly higher $(\alpha<0.001)$ than the age indicated for all patients studied (57 years). CVC occurred in $169(36.3 \%)$ patients in the SDG tested: in $51(64.5 \%)$ with STd and in $118(30.9 \%)$ without STd (Table 2). The two percentages differ significantly $(\alpha<0.001)$.

Tables 3 and 4 present accordingly the values of the total and of the lethal CRI according to SDG and age intervals accepted by the WHO. 


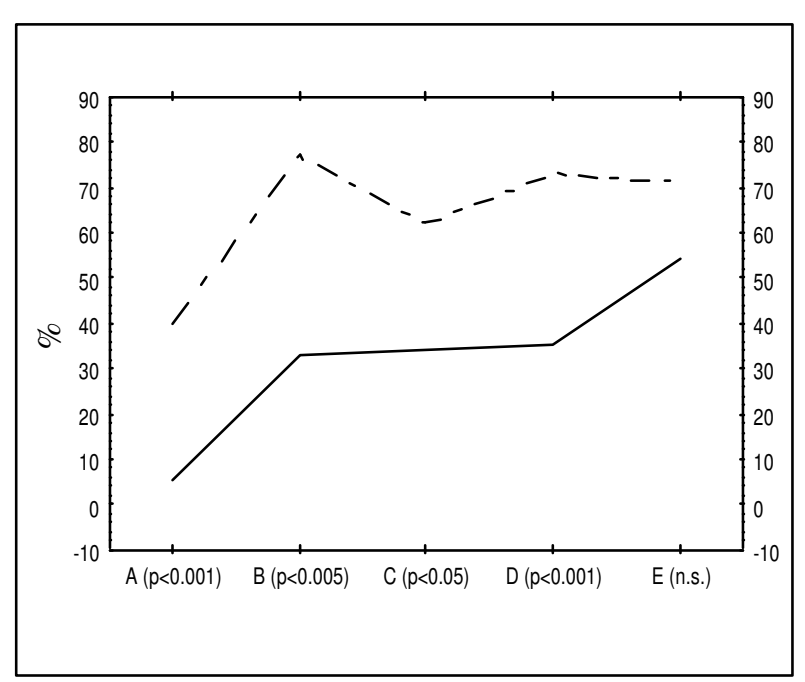

Fig. 1. Frequency of CVC:

without STd

-.-.- with STd

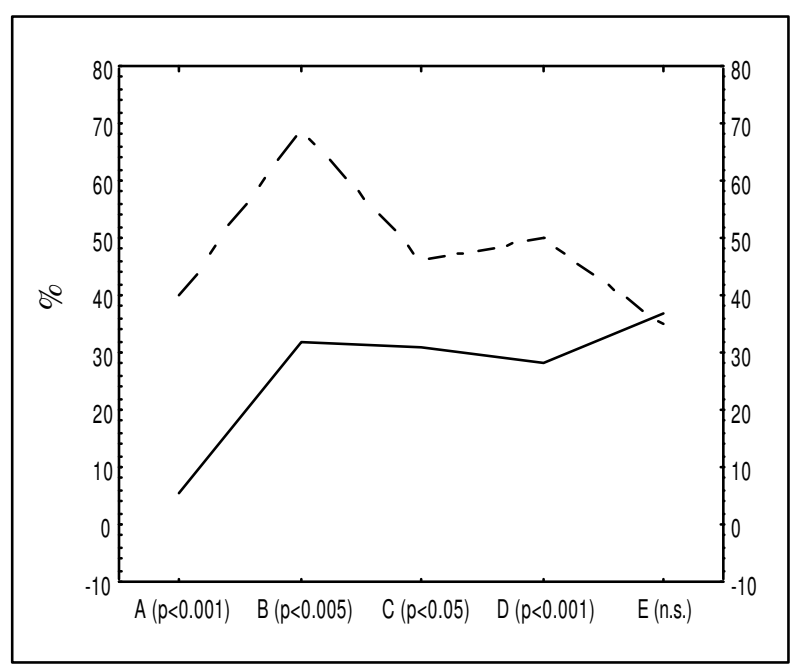

Fig. 3. Frequency of non lethal CVC: without STd -.-- $\quad$ with STd

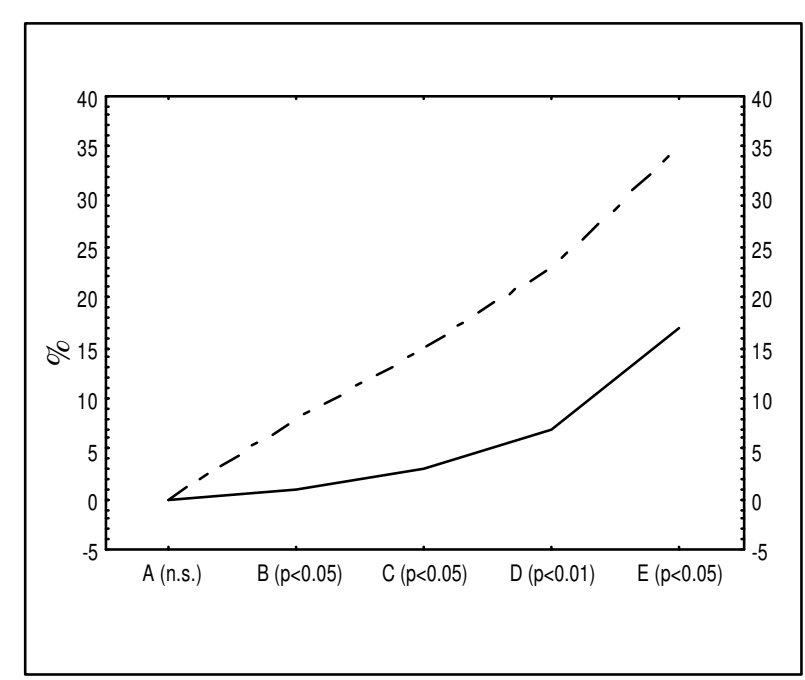

Fig. 2. Frequency of lethal CVC:

without STd

-.-.- $\quad$ with STd

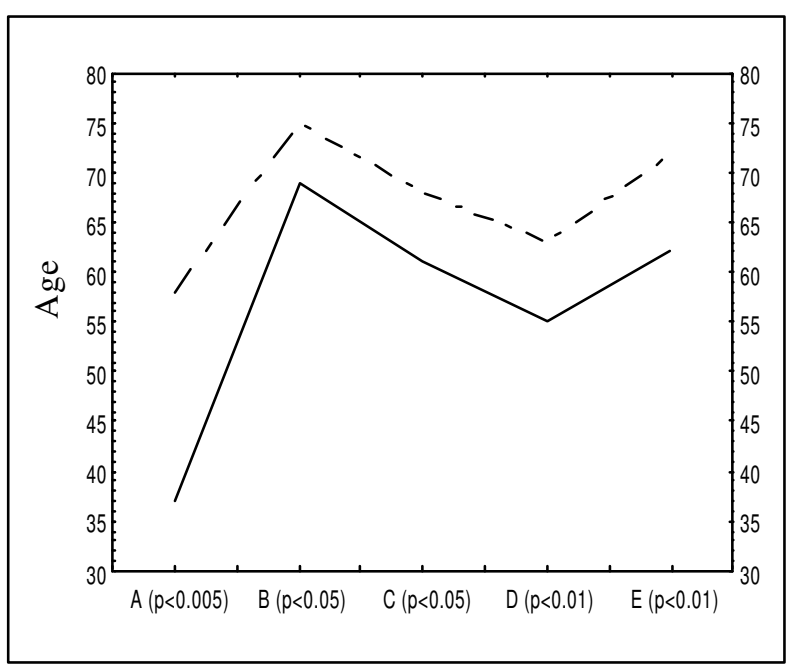

Fig. 4. Mean age in SDG: __ without STd -.-.- $\quad$ with STd

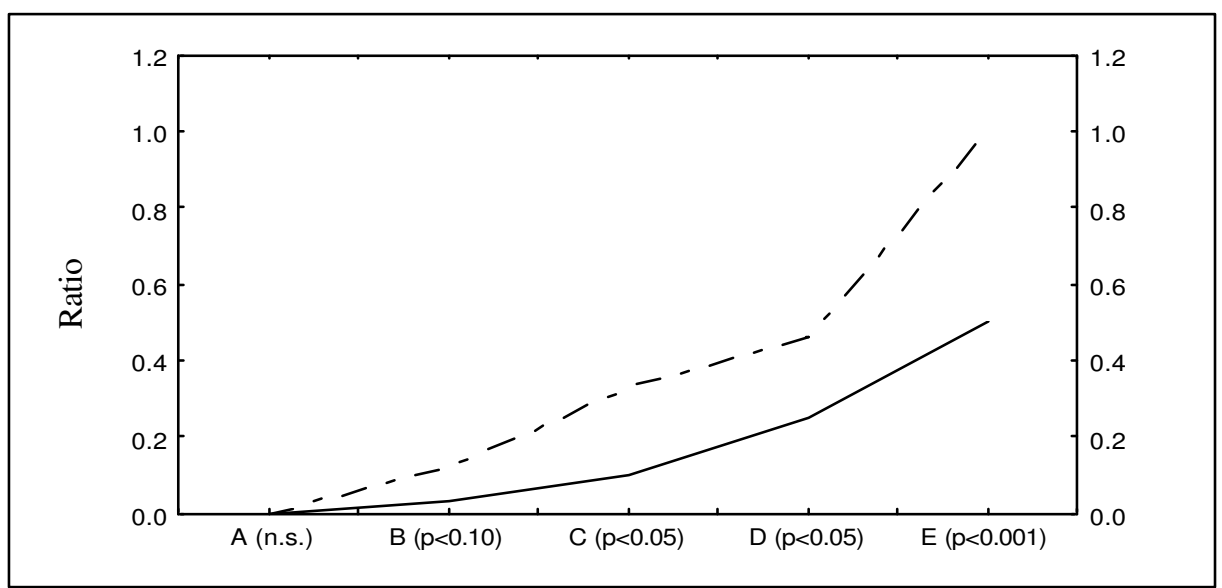

Fig. 5. Ratio of the frequencies of lethal and nonletal CVC: __ without STd -.-.- with STd 
Table 3. Values of TCRI according to SDG and age intervals

\begin{tabular}{ccccccc}
\hline Age $>$ & $18-40$ & $41-55$ & $56-65$ & $66-75$ & $76-90$ & $>90$ \\
\hline A & $1.4-3.2$ & $3.2-4.3$ & $4.3-5.1$ & $5.1-5.9$ & $5.9-7.1$ & $>7.1$ \\
B & $0.5-1.1$ & $1.1-1.5$ & $1.5-1.8$ & $1.8-2.1$ & $2.1-2.5$ & $>2.5$ \\
C & $0.4-0.95$ & $0.95-1.3$ & $1.3-1.5$ & $1.5-1.8$ & $1.8-2.2$ & $>2.2$ \\
D & $0.5-1.2$ & $1.2-1.7$ & $1.7-2.0$ & $2.0-2.3$ & $2.3-2.7$ & $>2.7$ \\
E & $0.3-0.6$ & $0.6-0.8$ & $0.8-1.0$ & $1.0-1.1$ & $1.1-1.4$ & $>1.4$ \\
\hline
\end{tabular}

Table 4. Values of LCRI according to SDG and age intervals.

\begin{tabular}{ccccccc}
\hline Age $>$ & $18-40$ & $41-55$ & $56-65$ & $66-75$ & $76-90$ & $>90$ \\
\hline A & 0 & 0 & 0 & 0 & 0 & 0 \\
B & $0.06-0.13$ & $0.13-0.18$ & $0.18-0.22$ & $0.22-0.25$ & $0.25-0.30$ & $>0.30$ \\
C & $0.13-0.31$ & $0.31-0.43$ & $0.43-0.50$ & $0.50-0.59$ & $0.59-0.73$ & $>0.73$ \\
D & $0.22-0.53$ & $0.53-0.75$ & $0.75-0.88$ & $0.88-1.01$ & $1.01-1.19$ & $>1.19$ \\
E & $0.30-0.60$ & $0.60-0.80$ & $0.80-1.00$ & $1.00-1.10$ & $1.10-1.40$ & $>1.40$ \\
\hline
\end{tabular}

\section{Discussion and conclusions}

The prediction of CVC in emergency abdominal surgery is very important in view of their high frequency in the population studied. The significantly higher frequency of CVC in the patients with STd proves that real and the relative myocardial ischaemia constitute an autonomous and significant risk factor. STd determines not only the risk of occurrence of CVC, but also its severity: entirely non-lethal CVC (group A); predominantly non-lethal CVC (groups B, C, D); predominantly lethal CVC (group A).

The precise assessment of the role of STd as a risk factor requires to take specifically into account the contribution of age in the incidence of CVC in patients with and without STd. In this aspect the values of the

\section{References}

[1] Larsen SF, Olesen KH, Jacobsen E, et al: Prediction of cardiac risk in noncardiac surgery. Eur Heart J 1987;8:17985.

[2] Guidelines for Perioperative Cardiovascular Evaluation for noncardiac surgery. Report of ACC/AHA Task Force. Circulation 1996;93:1286-1317.

[3] Goldman L, Assessment of the patient with known or suspected ischemic heart disease for noncardiac surgery. Br J Anesthesiol 1988;61:38-43. indices derived determine the following risk of CVC:

-for group A (low surgical severity): low risk of occurrence of mild CVC among young patients who dominate in the group; relatively high risk of mild CVC in the patients in advanced age;

-for group B (relatively low surgical severity): high risk of mild CVC due to the high mean age specific for this SDG;

-for groups C and D (increased surgical severity): growing risk of mild CVC with the increase in age; growing risk of severe $\mathrm{CVC}$ with increasing the severity of surgical disease;

-for group A (considerable surgical severity): due to the specific high mean age high risk of severe CVC; the risk of mild CVC is identical in patients with and without STd.

[4] Goldman L, Braunwald E. General anaesthesia and noncardiac surgery in patients with heart disease. In: Braunwald E., ed. Heart Disease, 4th ed., Philadelphia: Sounders, 1992:1708-20.

[5] Fleiss JL. Statistical Methods for Rates and Proportions. Sec. ed. John Wiley \& Sons, New York, 1988.

Address for correspondens

Mikhail Matveev

CLBME, Acad. G.Bonchev Str., Bl.105, 1113 Sofia, Bulgaria E-mail address mgm@clbme.bas.bg 